\title{
Blood-Lead levels among Inhabitants of Enyigba Lead-Zinc Mining Community of Ebonyi State, Nigeria: Indications of Occupational and Environmental Health Hazards
}

\author{
Bello H Tilako¹, Fred C Otuu ${ }^{2 *}$, Bassey E Bassey ${ }^{3}$ and Elvis N Shu ${ }^{4}$ \\ ${ }^{1}$ Directorate of Medical Laboratory Services, Ministry of Health Gombe, Gombe State, \\ Nigeria \\ 2Department of Pharmaceutics, University of Nigeria, Nsukka, Enugu State, Nigeria \\ ${ }^{3}$ World Health Organization Office, Central Business District, Nigeria \\ ${ }^{4}$ Department of Pharmacology and Therapeutics, University of Nigeria, Nigeria
}

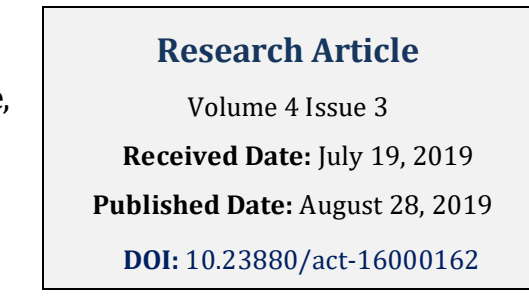

*Corresponding author: Fred C Otuu, Department of Pharmaceutics, University of Nigeria Nsukka, Enugu State, Nigeria, Tel: +234 703245 4222; Email: fred.otuu@unn.edu.ng

\section{Abstract}

Background: Artisanal mining activities have become a significant occupation among the inhabitants of Enyigba community in Ebonyi State, Nigeria.

Objective: This study investigated the blood-lead levels of some subjects of Enyigba lead-zinc mining community.

Methods: A questionnaire on health hazards and safety measures associated with the mining activities was administered to the participants. Blood samples were collected for the analysis of blood-lead levels by standard methods.

Results: Males dominated in the occupationally-exposed (56.18\%) and females (62.30\%) dominated in the environmentally-exposed. Almost all the occupationally-exposed subjects (96.63\%) and environmentally-exposed subjects (80.33\%) store mined products in their houses. Majority of the occupationally-exposed subjects (69.67\%) were not aware of the hazards and safety measures, and $75.28 \%$ did not use personal protective devices. Headache (74.40\%) was reported as the most prevalent sickness. The occupationally and environmentally-exposed subjects had mean bloodlead levels of $42.30 \mu \mathrm{g} / \mathrm{dl}$ and $28.67 \mu \mathrm{g} / \mathrm{dl}$, respectively, which were significantly higher $(\mathrm{p}<0.0001)$ than the control levels. Conclusion: Given the increasing participation of many households in lead mining activities and the storage of the lead products in homes, lead contamination may remain a significant public health issue in the study area.

Keywords: Blood-Lead Levels; Occupationally-Exposed; Environmentally-Exposed; Health Hazards; Safety Measures

\section{Introduction}

With the discovery and exploration of solid minerals in Abakaliki division of the old Eastern Nigeria, in the nineteen-forties, artisanal mining activities have become a significant occupation among the inhabitants, to the extent that virtually every household within the mining area is involved in artisanal mining. This has affected the 
environment of the mining areas negatively, as heaps of mining tails are scattered everywhere, and lead-zinc metals are heaped in most households, exposing the inhabitants to metal pollution. Studies so far on the impacts of mining in Abakaliki lead-zinc mining area have focused mainly on water, soil, and plant metal loads and their speculative health and environmental impacts [1-4]. The impact of lead-zinc mining on plant physiology, anatomy and biochemistry are also available in local and international literatures [5-8]. However, there is scarcity of literature on the impacts of lead-zinc mining activities on the specific health status of inhabitants of the mining environment.

Many serious health concerns may arise from the uptake of heavy metal contaminated food or water. A decrease in immunological defenses, intra-uterine growth retardation, impaired psycho-social behavior, and disabilities associated with mal-nutrition are some of the many health concerns [9]. The disease burden imposed by mining pollution affects children greatly and over 70 percent of these children face hazardous conditions [10]. Children, who are more vulnerable to the impacts of heavy metals, tend to have higher exposures and generally account for the majority of deaths and diseases associated with mass poisoning incidents from the mining operations. Studies have documented that children involved in mining have higher exposures to mercury, lead, and other metals and suffer severe lead and mercury intoxication [10]. Lead-zinc mining has assumed significant occupation in Enyigba community such that even children of preschool age are also involved directly when they are strapped on their mothers' backs during mining or indirectly when they are exposed to the mining heaps in the household.

The heavy metals such as zinc, copper, cadmium, iron, selenium, cobalt, nickel, arsenic and mercury tend to have very high enrichment factor and slow clearance rate [11]. The accumulation of these heavy metals in sediments and water is a major health concern because of the removal of such metals by plants and the resultant exposure of human and animal life to the elevated metals through the food chain. However, because of the illegal nature of artisanal mining, there is a need for research to assess the severity of environmental and occupational problems resulting from their activities. Such studies will serve to show the magnitude of the problems, indicate likely initiatives required to arrest arising potential and associated environmental and social conflicts, and provide cognitive basis for informed intervention policies by government.
There is extensive evidence that measures of bodylead burden are associated with lead levels in environmental media $[12,13]$. Three of the measures of body-lead burden reported in the literature are bone-lead content, blood-lead concentration, and erythrocyte protoporphyrin (EP) blood concentration. Bone-lead levels are considered to be reflective of cumulative exposure to lead, but their determination is currently either expensive or invasive. More importantly, the accuracy and representativeness of bone-lead concentrations measured externally by x-ray fluorescence (XRF) instrument has been questioned by researchers [14]. Blood-lead and EP levels can be more readily measured, but reflect a varying mixture of long-term and more recent exposures [15-17]. Despite the complex interaction of prior and current exposures, evident in measured blood-lead concentrations, they are still the measure of choice for most studies of intervention effectiveness. There is a body of literature relating bloodlead concentrations to specific health outcomes stemming from lead exposure, though much of it examined children with levels of exposure usually indicative of lead poisoning [12]. Blood-lead concentration is associated with environmental lead exposure and linked to health outcomes. In this study, blood-lead levels were used as indices of environmental/occupational exposure to lead contamination.

\section{Methodology}

\section{Description of the Study Area}

Ebonyi State of Nigeria occupies a landmass of approximately $5,935 \mathrm{~km} 2$, and lies on approximately latitude $70301 \mathrm{E}$ to $80301 \mathrm{E}$ and longitudes $50401 \mathrm{~N}$ to $60451 \mathrm{~N}$. The State is bounded to the East by Cross River State, to the West by Enugu State, to the South by Abia State and to the North by Benue State of Nigeria [18]. Abakaliki is the Capital City of Ebonyi State. The City is in the mid of the South Eastern Nigeria and lies within the mineralized zone of lead - zinc deposits of the River Benue trough, which stretches for hundreds of kilometers north-easterly from Zurak [19]. The Benue trough is one of the known major areas with $\mathrm{Pb}-\mathrm{Zn}$ deposit in West Africa. Abakaliki, especially the Enyigba area which is about $14 \mathrm{Km}$ south of Abakaliki urban, isoverlain with tropical rocks which constitute gneisses, granites, shales, sphalerite and crustal rocks [20]. The prevailing climate is tropical with high rainfall, high temperature, high atmospheric humidity and precipitation usually exceeding evapotranspiration for more than half the year. The Enyigba $\mathrm{Pb}-\mathrm{Zn}$ Mine was intermittently mined for lead 
from 1925 though mining operations ceased during the Nigerian Civil War (1967-1970) that badly affected the industry, but has recently been activated with artisanal mining activities highly pronounced.

\section{Subjects}

This study was carried out on 150 subjects who have lived in the community from 2 years and above. The miners comprised of both sexes between the ages of 6 years and 65 years. Voluntary, first person Informed Consent of the participants was obtained. The protocol for the study was reviewed and approved by the Research Ethics Committee of the Ebonyi State Ministry of Health, Abakaliki.

\section{Study Design}

The study design was cross-sectional and assessed the most common diseases suffered by the miners. The questionnaire captured background variables (bio-data) and questions that were aimed at obtaining answers to the objectives of the study. Blood samples were collected from the miners through venous puncture.

\section{Administration of Questionnaires}

Well-structured questionnaires designed to reflect demography, prevalent diseases, awareness on health hazards associated with the mining and knowledge of safety measures to minimize hazards, were administered to the miners. Selected community members (two males and three females) and three health personnel consisting of two medical laboratory Scientists and one Medical Doctor were recruited for the exercise. They were given structured training that enabled them to obtain appropriate responses from the participants. The Doctor did on the spot physical examination on the miners. The response was hundred percent successful.

\section{Collection and Analysis of the Blood Samples}

Blood samples (4mls) were collected by venopuncture into plain vacutaner bottles. The blood samples were analyzed for blood-lead levels using FS 240AA atomic absorption spectrophotometer (Agilent Technology, USA) according to the method of American Public Health Association [21].

\section{Results}

The results of the study are presented in Tables 1 to 5 . Table 1 represents the demography of the subjects in the study area. The subjects were dominated by males in the occupationally exposed (56.18\%) and in the controls $(53.85 \%)$ and but by females (63.30\%) in the environmentally exposed. Most of the subjects in the occupationally exposed were singles $(52.81 \%)$, but most of them in the environmentally exposed $(72.28 \%)$ and controls (53.83\%) were married. Majority of the subjects had at least primary education. The predominant age range for the occupationally exposed $(29.21 \%)$ and controls (35.38\%) was 21-30 years, but for the environmentally exposed, it was 41-50 years. The dominant duration of stay in the community was $>25$ years for the occupationally exposed (40.46\%), environmentally exposed (54.10\%) and controls (35.39\%). Almost all the occupationally exposed subjects $(96.63 \%)$ and environmentally exposed subjects $(80.33 \%)$ stored mined products in their houses. The largest population of the subjects (65.17\%) had engaged on lead-zinc mining activities for less than 5yrs, followed by $6-10$ years $(22.86 \%)$ (Table 2$)$.

\begin{tabular}{|c|c|c|c|}
\hline Variable & Occupationally Exposed n (\%) & Environmentally Exposed n (\%) & Control n (\%) \\
\hline \multicolumn{3}{|c|}{ Sex } \\
\hline Male & $50(56.18)$ & $23(37.70)$ & $35(53.85)$ \\
\hline Female & $39(43.82)$ & $38(62.30)$ & $30(46.15)$ \\
\hline Total & 89100.00 & 61100.00 & 65100.00 \\
\hline \multicolumn{2}{|c|}{ Age (Yrs) } \\
\hline \hline 10 & $05(05.62)$ & $10(16.39)$ & $05(07.69)$ \\
\hline $11-20$ & $22(24.72)$ & $03(04.92)$ & $08(12.31)$ \\
\hline $21-30$ & $26(29.21)$ & $04(06.56)$ & $18(35.38)$ \\
\hline $31-40$ & $23(25.84)$ & $12(19.67)$ & $07(10.77)$ \\
\hline $41-50$ & $05(05.62)$ & $17(27.87)$ & $02(03.08)$ \\
\hline $51-60$ & $07(07.87)$ & $10(16.39)$ & $02(03.08)$ \\
\hline$>60$ & $01(01.12)$ & $05(08.20)$ & 65100.00 \\
\hline Total & 89100.00 & 61100.00 & \\
\hline
\end{tabular}

Fred C Otuu, et al. Blood-Lead levels among Inhabitants of Enyigba Lead-Zinc 


\begin{tabular}{|c|c|c|c|}
\hline \multicolumn{4}{|c|}{ Marital status } \\
\hline $\begin{array}{c}\text { Married \& staying with } \\
\text { spouse }\end{array}$ & $39(43.82)$ & $44(72.13)$ & $35(53.82)$ \\
\hline \begin{tabular}{c|} 
Single \\
\end{tabular} & $47(52.81)$ & $12(19.67)$ & $28(43.08)$ \\
\hline Widow/Widower & $03(03.37)$ & $05(08.20)$ & $02(03.10)$ \\
\hline Total & 89100.00 & 61100.00 & 65100.00 \\
\hline \multicolumn{4}{|c|}{ Educational level } \\
\hline NonFormal Education & $08(08.99)$ & 17 (27.87) & $07(10.77)$ \\
\hline Primary & $29(32.58)$ & $34(55.74)$ & $17(26.15)$ \\
\hline Secondary & $49(55.06)$ & 07 (11.47) & $35(53.85)$ \\
\hline Tertiary & $03(03.37)$ & $03(04.92)$ & $06(09.23)$ \\
\hline Total & 89100.00 & 61100.00 & 65100.00 \\
\hline \multicolumn{4}{|c|}{ Duration in the community (Yrs) } \\
\hline$<5$ & $09(10.11)$ & $12(19.67)$ & $07(10.77)$ \\
\hline $6-10$ & $09(10.11)$ & $08(13.11)$ & $04(06.15)$ \\
\hline $11-15$ & $15(16.85)$ & $02(03.28)$ & $11(16.92)$ \\
\hline $16-20$ & $17(19.10)$ & $02(03.28)$ & $14(21.54)$ \\
\hline $21-25$ & $03(03.37)$ & $04(06.56)$ & $06(09.23)$ \\
\hline$>25$ & $36(40.46)$ & $33(54.10)$ & $23(35.39)$ \\
\hline Total & 89100.00 & 61100.00 & 65100.00 \\
\hline \multicolumn{4}{|c|}{ Storage of mined products in the house } \\
\hline Yes & $86(96.63)$ & $49(80.33)$ & - \\
\hline No & 03 (03.37) & $12(19.67)$ & - \\
\hline Total & $89(100.00)$ & $61(100.00)$ & - \\
\hline
\end{tabular}

Table 1: Demographic Features of the Study Population.

\begin{tabular}{|c|c|c|}
\hline \multirow{2}{*}{$\begin{array}{c}\text { Duration of Pb -Zn mining } \\
\text { (Yrs) }\end{array}$} & \multicolumn{2}{|c|}{$\begin{array}{c}\text { Occupationally } \\
\text { Exposed }\end{array}$} \\
\cline { 2 - 3 } & $\mathbf{n}$ & $\mathbf{( \% )}$ \\
\hline$<5$ & 58 & 65.17 \\
\hline $6-10$ & 20 & 22.46 \\
\hline $11-15$ & 4 & 4.49 \\
\hline $16-20$ & 5 & 5.62 \\
\hline $21 \&$ above & 2 & .2 .25 \\
\hline Total & 89 & 100 \\
\hline
\end{tabular}

Table 2: Duration of Lead-Zinc Mining.

Table 3 presents the awareness of occupational hazards and safety measure utilization of the subjects. Majority of the 89 occupationally exposed subjects $(69.67 \%)$ were not aware of the hazards associated with their job and as a result, only $22(24.72 \%)$ used personal protective devices. Among the 22 who agreed subjects to have been using protective devices, only $13.64 \%$ used them regularly? Safety boots $(50.10 \%)$ were reported as the commonly used protective devices by the subjects.

\begin{tabular}{|c|c|c|}
\hline Variable & Frequency & $\%$ \\
\hline \multicolumn{3}{|c|}{ Do you know there are hazards involve in the job? } \\
\hline Yes & 27 & 30.33 \\
\hline No & 62 & 69.67 \\
\hline Total & 89 & 100 \\
\hline \multicolumn{3}{|c|}{ Do you use any safety devices for protection? } \\
\hline Yes & 22 & 24.72 \\
\hline No & 67 & 75.28 \\
\hline Total & 89 & 100 \\
\hline \multicolumn{3}{|c|}{ How often do you use these safety devices? } \\
\hline Regularly & 3 & 13.64 \\
\hline Occasionally & 19 & 86.36 \\
\hline Total & 22 & 100 \\
\hline \multicolumn{3}{|c|}{ Types of personal safety devices used } \\
\hline Aprons & 3 & 13.63 \\
\hline Dust masks & 8 & 35.36 \\
\hline Goggles & 7 & 31.82 \\
\hline Hand gloves & 9 & 40.9 \\
\hline Safety boots & 13 & 50.1 \\
\hline
\end{tabular}

Table 3: Knowledge of Work Place Hazards and Safety Measure. 
Table 4 represents self-reported occupational health problems among subjects. Most of the subjects (74.40\%) reported that they had headache followed by itching (53.93\%) and dizziness (40.45\%)

\begin{tabular}{|c|c|c|}
\hline Symptoms & Frequency & $\mathbf{\%}$ \\
\hline Headache & 68 & 74.4 \\
\hline Skin irritation & 29 & 32.58 \\
\hline Dizziness & 36 & 40.45 \\
\hline Itching & 48 & 53.93 \\
\hline Joint pain & 17 & 19.1 \\
\hline Waist pain & 13 & 14.6 \\
\hline Weight loss & 8 & 8.99 \\
\hline Cough & 12 & 13.48 \\
\hline Anxiety & 8 & 10.11 \\
\hline Chest pain & 8 & 8.99 \\
\hline No symptoms & 5 & 5.62 \\
\hline
\end{tabular}

Table 4: Prevalent Occupational Health Problems among Subjects.

Table 5 represents blood-lead levels of the inhabitants in the study and control areas. The subjects who were occupationally-exposed to lead contamination had mean blood-lead levels of $42.30 \mu \mathrm{g} / \mathrm{dl}$, while the environmentally-exposed had average subject's bloodlead levels of $28.67 \mu \mathrm{g} / \mathrm{dl}$. Both values were significantly higher $(\mathrm{p}<0.0001)$ than the control value $(4.76 \mu \mathrm{g} / \mathrm{dl})$ and the WHO recommended maximum exposure level of $10 \mu \mathrm{g} / \mathrm{dl}$. The blood lead levels of the occupationallyexposed individuals were also significantly higher $(p<0.0001)$ than that of the environmentally exposed subjects.

\begin{tabular}{|c|c|c|}
\hline \multirow{2}{*}{ Subjects } & \multicolumn{2}{|c|}{ Blood lead levels $(\boldsymbol{\mu g} / \mathbf{d l})$} \\
\cline { 2 - 3 } & Mean & Standard Deviation \\
\hline $\begin{array}{c}\text { Occupationally } \\
\text { exposed }\end{array}$ & $* 42.30$ & 10.9 \\
\hline $\begin{array}{c}\text { Environmentally } \\
\text { exposed }\end{array}$ & $* 28.67$ & 9.12 \\
\hline Control & 4.76 & 2.1 \\
\hline
\end{tabular}

Table 5: Blood Lead Levels of Subjects in the Study Area. $* \mathrm{P}<0.0001$.

\section{Discussion}

This study investigated the blood-lead levels of one hundred and fifty (150) subjects of Enyigba lead-zinc mining community who voluntarily participated in the study. The participants were grouped into occupationally and environmentally exposed subjects. The occupationally exposed subjects were those who were involved in lead-zinc mining activities as a significant source of income. The environmentally exposed subjects were those who were not involved in the mining activities but were exposed to lead contamination through environmental media such as soil, air and water, and environmental components such as foods and household storage facilities, because they live within the mining community. The awareness of the hazards associated with the lead-zinc mining activities and the necessary safety measures against the occupational hazards were also investigated. The difference in blood-lead levels among the occupationally exposed in comparison with the environmentally exposed was used as an evidence of occupational hazards associated with the lead-zinc mining activities in Enyigba.

The result of the demography showed that male were actively involved in the lead-zinc mining activities, probably more involved than women, because the population of the male subjects $(56.18 \%)$ was higher than women (43.82\%). This could be explained from the fact that lead-zinc mining activities have become major occupations second only to farming activities in the leadzinc mining communities of Abakaliki ${ }^{18}$. In most communities of Ebonyi state, subsistence farming is a common practice with men. With the recognition of the economic value inherent in artisanal lead-zinc mining, the gradual shift from agricultural dominated economic base to mixed economic base, the emergence of artisanal men miners is a strong possibility. The sieving of stream sediments and sorting of lead from the mining tails seem attractive and fitting to more men than women. The absence of divorcées among the subjects presupposed strong marriage bond. This could also favor women participation in the mining activities as some of the men are polygamous, a culture commonly found in Abakaliki rural communities. Polygamy is culturally accepted among rural agricultural communities since it means more helping hands to the husbands in their farms.

Ebonyi State in general is considered an educationally disadvantaged State among the south-eastern States. This accounts for the greater number of subjects with secondary education (55.06\%). The few subjects (3.37\%) with tertiary education were not entirely indigenes of the community, as some were civil servants (teachers, construction workers) whose involvements with lead-zinc mining were pastime. 
The storage of the mining products in the house was a common feature with the miners (96.63\%) and environmentally exposed (80.333\%). This could be explained by the fact that most of the subjects (69.67\%) had no awareness of the hazards associated with lead contamination through dietary and environmental exposures. The lack of hazard awareness could also be attributed to inadequate education. In the present educational standard ravaging the national educational system, primary school education is close to illiteracy. The greater use of safety boots by the subjects $(50.10 \%)$ might not be for safety against lead contamination, but rather for protection against sharp objects (stones, gravels, thistles) piercing the feet. This argument could be supported by the fact that many of the subjects agreed to have been using safety boots in their regular farming activities, especially during the rainy season. Some of the self-reported occupational health problems among the subjects were also those associated with lead contamination and activities involving weight lifting, long hours of bending down and stooping low.

There was a significant differences $(p<0.0001)$ in the blood-lead levels of the occupationally and environmentally exposed respondents. The subjects who were occupationally exposed were also environmentally exposed, accounting for relatively higher mean blood-lead levels $(42.30 \mu \mathrm{g} / \mathrm{dl})$ than the environmentally exposed $(28.67 \mu \mathrm{g} / \mathrm{dl})$.

In general the blood levels of both groups were higher than the control group $(4.76 \mu \mathrm{g} / \mathrm{dl})$ and also higher than the WHO recommended maximum exposure level of 10 ug/dl [22]. This observation poses a public health problem realizing the implication of lead contamination in a myriad of diseases. Lead, Zinc and Cadmium have been implicated in a number of diseases owing to their roles in creation of oxidative stress with the associated morphological distortion and biochemical disruption [23]. The destruction of sensitive thiol groups by metal interaction may negatively affect the protein folding/ or binding of apoenzymes by cofactors, resulting in deformation of the normal biological activity of the proteins [24]. Lead, like some other heavy metals can participate in catalytic reactions, known as Fenton-type reactions that produce Reactive Oxygen Species (ROS), setting the cell under an oxidative stress which may result in DNA damage, destructions of lipids and proteins through a wide range of biochemical routes [25]. Lead and other heavy metal species may also get into cells through various transport routes, or penetrate the cellular membrane to bind to lipophilic carrier. This transporter-mediated uptake of toxic heavy metals interferes with the normal transport of essential substrates, resulting in competitive inhibition of the transport process necessary for nutrient normal haemostatic processes. Significantly, transportation of heavy metals across the membrane barriers may require acquisition of energy from the proton motive force or ATP pool, interrupting the role of ATP in cellular metabolism. This underlies the many metabolic diseases traceable to heavy metal intoxication [26].

Occupational and environmental exposures continue to be a serious global problem, especially in developing or rapidly industrializing countries [27]. This is in line with the present study where crude artisanal mining activities characterized by unregulated disposal of mining tails, lack of awareness of safety measures and ignorance of health effects of lead contamination have resulted in the high blood-lead levels among the sampled subjects. Developing country populations, especially children, may have higher levels of lead exposure due to unregulated industrial emission and car emission of leaded petrol; less stringent environmental and occupational health safety regulation, and cottage (domestic) industries such as metal polishing and smelters [28]. In view of the increasing participation of households in lead mining activities in the Enyigba community and persistence of lead in the environment, the issue of lead contamination is likely to remain a significant public health issue in the study area.

In Abakiliki lead-zinc mining communities, outdoor environmental pollution plays a significant role in indoor lead exposure. The ignorance of the miners (adults and children) of lead contamination through work-clothes, implements, and storage has contributed to extraneous lead contamination of the house-hold from the field [29]. Breaking the chain-flow of lead from the field to the home through holistic education will minimize the quantity of house-hold lead, thereby reducing environmental exposure of non-miners, especially children and aged ones in the household.

\section{Acknowledgment}

Authors acknowledged the assistance of the community leaders who made it possible for peaceful community entry to be achieved.

\section{Conflict of Interest}

\section{None}




\section{Advances in Clinical Toxicology}

\section{References}

1. Edeogu CO, Ekuma CE, Okaka ANC, Ezeonu FC, Uneke CJ, et al. (2007) Public health significance of metals concentration in soils, water and staple foods in Abakaliki South Eastern Nigeria. Trends Appl Sci Res 2(5): 439-444.

2. Ezeh HN, Chukwu E (2011) Small scale mining and heavy metals pollution of Agricultural soils: The case of Ishiagu Mining District, South Eastern Nigeria. J Geo and Min Res 3(4): 87-104.

3. Utumoh EJ, Uraku AJ, Omaka ON, Nwabue FI (2012) Glo J. Bio-sci Bio-tech 1(2): 320-323.

4. Oti WJO, Nwabue FI (2013) Heavy metals affect due to contamination of vegetables from Enyigba lead mine in Ebonyi State, Nigeria. Environ Pol 2(1): 1926.

5. Suruchi, Pankaj K (2011) Assessment of heavy metal contamination in different vegetables grown in and around urban areas. Res J Environ Toxicol 5(3): 162179.

6. Okogbue CO, Ukpai SN (2013) Evaluation of trace element contents in groundwater in Abakaliki metropolis and around the abandoned mine sites in the southern part, Southeastern Nigeria. Environ Earth Sci 70(7): 3351-3362.

7. Ogbonna CE, Okeke CU, Ugbogu CO, Otuu FC (2013) Leaf epidermal analysis of some plants in the Ishiagu lead-zinc mining area of South Eastern Nigeria. Int J Biosci 3(11): 112-128.

8. Otuu FC, Shu, EN, Aloh O (2018) Environmental Pollution and Food Quality-Impact of Lead-Zinc Mining on Four Staple Foods. Lambert Academic Publishing.

9. Nweke OC, Sanders WH (2009) Modern environmental health hazards: a public health issue of increasing significance in Africa. Environ Health Perspect 117(6): 863-870.

10. Lo YC, Dooyema CA, Neri A, Durant J, Jefferies T, et al. (2010) Childhood Lead Poisoning Associated with Gold Ore Processing: a Village-Level InvestigationZamfara State, Nigeria. Environmental Health Perspectives 120(10): 1450-1455.
11. Yoon J, Cao X, Zhou Q, Ma QL (2006) Accumulation of $\mathrm{Pb}, \mathrm{Cu}$ and $\mathrm{Zn}$ in Native Plants Growing in a Contaminated Florida Site. Sci. Total Environ 368(23): 456-464.

12. USEPA (1996) Effect of in-home educational intervention on children's blood lead levels in Milwaukee. HE20.P6.E5. Washington, DC: US. Environmental Potential Agency.

13. Centers for Disease Control (CDC) (1991) Preventing Lead Poisoning in Young Children - A Statement by the Centers for Disease Control. Atlanta: U.S. Department of Health and Human Services October.

14. Wedeen RP (1988) Bone lead, hypertension, and lead nephropathy. Environ Health Perspect 78: 57-60.

15. ATSDR (1993) Toxicological Profile for lead. Final Report of the Agency for Toxic Substances and Diseases Registry, Public Health Service, US Department of Health and Human Services.

16. Janin Y, Couinaud C, Stone A, Wise L (1985) 'The leadinduced Collic' syndrome in lead intoxication. Surg Annal 17: 287-307.

17. Hernberg S, Nikkanen J, Mellein G (1970) $\delta$ Aminolevulinic Acid Dehydrates as a measure of lead exposure. Archive of Environmental Health 21: 140145

18. Aloh OG, Aloh HE, Obasi NA, Chukwu K (2017) Evidence of heavy metal contamination of agricultural soil in Ameri, Abakaliki lead-zinc mining area, Ebonyi state Southeast Nigeria: An indication for phytoremediation. Nutr Food Tech 3(3): 1-5.

19. Olade MA, Morton RD (1985) Origin of lead-zinc mineralization in the southern Benue Trough, Nigeria - Fluid inclusion and trace element studies. Mineralium Deposita 20(2): 76-80.

20. Chukwama C (1993) Cadmium, lead, and zinc from terrestial plants in the Enyigba-Abakaliki lead and zinc mine: Search for a monitoring plant species in trace element distribution. Bull Environ Contam Toxicol 51(5): 665-671.

21. (1999) American Public Health Association. Direct air acetylene flame method, standard method for examination of metals, $20^{\text {th }}(\mathrm{Edn})$. 
22. World Health Organisation (2009) Levels of lead in children blood. European Environment and Health Information System.

23. Mizrahi L, Achituv Y (1989) Effect of heavy metals ions on enzyme activity in the Mediterranean mussel, Donax trunculus. Bulletin of Environmental Contamination and Toxicology 42(6): 854-589.

24. Tasleem JA, Mudsser A, Kehkasha S, Arif A, Inho C, et al. (2015) Heavy metals and human health, mechanistic insight into toxicity and counter defence system of antioxidant. Int J Mol Sci 16(12): 2959229630.

25. Jadoon S, Malik A (2017) DNA Damage by Heavy Metals in Animals and Human Beings: An Overview. Biochem Pharmacol 6(3): 235.
26. Lohmeier-Vogel EM, Shiela U, Raymond JT (2004) In vivo ${ }^{31} \mathrm{P}$ nuclear magnetic resonance investigation of tellurite toxicity in Escherichia coli. Appl Environ Micro 70(12): 7342-7347.

27. Tong S, von Schirnding YE, Prapamontol T (2000) Environmental lead exposure: A public health problem of global dimensions. Bull World Health Organ 78(9): 1068-1077.

28. United Nations Environmental Program-United Nations Children Educational Fund (UNEP-UNICEF) (1997) Childhood lead poisoning: Information for advocacy and action.

29. Javier FC, McCormick DP, Alcock NW (1999) Lead screening among low-income children in Galvestone, Texas. Clin Pediatri 38(11): 655-660. 